\title{
Coexistent chlamydial infections related to natural history of human papillomavirus lesions in uterine cervix
}

\author{
K SYRJÄNEN,* R MÄNTYJÄRVI, $\dagger$ M VÄYRYNEN, $\ddagger$ S PARKKINEN, $\dagger$ H HOLOPAINEN, \\ S SYRJÄNEN,* S SAARIKOSKI, $\ddagger$ AND O CASTRÉN $\ddagger$
}

From the Departments of * Pathology, $\uparrow$ Clinical Microbiology, and $\ddagger$ Gynaecology and Obstetrics, University of Kuopio, Kuopio, Finland

SUMMARY To assess the role of Chlamydia trachomatis in the development of cervical intraepithelial neoplasia (CIN) and to evaluate possible synergism between chlamydiae and human papillomavirus (HPV) in this process, 418 women who had been prospectively followed up for cervical HPV infections at our clinic since 1981 were tested for chlamydiae. At each visit the patients were examined by colposcopy, and other investigations, such as Papanicolaou (Pap) smears, punch biopsies, urethral, and cervical swabs, were undertaken as indicated. In biopsy specimens the cytopathic changes of HPV, concomitant CIN, and the local immunocompetent cell infiltrates were analysed. The latter were measured and further identified using an alpha naphthyl acetate esterase (ANAE) technique to define $B$ cells, macrophages, and $T$ cells and using monoclonal antibodies to define T cell subsets, NK (natural killer cells), and Langerhans cells. Chlamydial isolation ( $4 \cdot 1 \%$ in the cervix, and $3.6 \%$ in the urethra) did not positively correlate with the degree of cytological atypia in PAP smears or with the degree of CIN lesions associated with HPV. Chlamydial cervicitis did not affect the ANAE definable cell composition of the immunocompetent cell infiltrates in HPV lesions, or that of the immunocompetent cell subsets, including the ratios of $T$ helper to $T$ suppressor cells and the numbers of NK cells. Chlamydial infection did not alter the natural history of HPV lesions, of which $30 \%$ regressed, $53 \%$ persisted, and $17 \%$ progressed during follow up. The present results do not provide evidence to substantiate the hypothesis that chlamydiae and HPV might act synergistically in cervical carcinogenesis, or the view that $C$ trachomatis may be a major aetiological agent of CIN lesions. Chlamydiae and HPV are covariables of sexual behaviour, and their concomitant appearance in sexually promiscuous women is best explained by this fact. As we do not have more direct evidence for the oncogenic potential of $C$ trachomatis (as we have of HPV), it seems reasonable to consider that this agent is not a major cause of CIN, but rather a sexually transmitted agent commonly found in women with CIN because of their promiscuous sexual behaviour.

\section{Introduction}

Chlamydia trachomatis, an obligate intracellular bacterium, ${ }^{1}$ is an increasingly common cause of gynecological infection in women attending sexually transmitted diseases (STD) clinics. ${ }^{2-9}$ Though pelvic

Address for reprints: Dr K Syrjänen, Laboratory of Pathology and Cancer Research, Finnish Cancer Society, Kiekkotie 2, SF-70200 Kuopio, Finland

Accepted for publication 14 November 1985 inflammatory disease (PID) may result from chlamydial infection, the most common feature of infection in women is cervicitis. ${ }^{2-11}$ There is little doubt that chlamydiae are sexually transmitted, ${ }^{2-11} 16$ and can induce cervicitis detectable by biopsy and in cervical Papanicolaou (Pap) smears. ${ }^{1} 67$ 12-15 Furthermore, an association between cervical chlamydial infection and cervical intraepithelial neoplasia (CIN) has been suggested because of higher than normal recovery rates of $C$ trachomatis (as well as the finding of specific serum antibodies to it) in women with CIN. ${ }^{5-7} 17-20$

Certain types of human papillomavirus (HPV 6, 11, 
$16,18,31,33$, and 35 ) are known to induce squamous cell lesions (condylomas) of the uterine cervix.$^{21}$ With epidemiological reports on the steadily increasing incidence and prevalence of CIN, especially in young sexually active women, substantial evidence has accumulated suggesting an intimate relation between cervical HPV infections and CIN, carcinoma in situ (CIS), and cervical cancer. ${ }^{21-28}$ Such data derive from the reports on the common coexistence of HPV and CIN lesions in cervical epithelium, from reports on malignant transformation of lesions induced by HPV in animals and in man, as well as from epidemiological surveys showing the risk factors in common for both HPV infections and cervical cancer. ${ }^{21-28}$ Furthermore, the expression of HPV structural proteins (viral antigens) has been repeatedly shown by immunoperoxidase (IP-Pap) techniques in CIN and CIS lesions, which suggests the existence of an HPV genome in such lesions. ${ }^{24} 26$ This was recently confirmed by DNA hybridisation that disclosed DNA of HPV in genital warts, lesions of CIN and CIS, and in invasive cervical carcinomas. ${ }^{29-33}$

Despite the progress made during the past few years, the final proof that HPV is an aetiological agent of cervical cancer still remains to be established. This is partly because of the scarcity of prospective follow up data on the natural history of these lesions. ${ }^{26} 3435 \mathrm{~A}$ hypothesis suggesting that herpes simplex virus(HSV) and HPV could act synergistically in cervical carcinogenesis $^{36}$ has been supported by evidence on coexistent HSV infection in $10 \%$ of women followed up for cervical HPV lesions. ${ }^{37}$ Few data are available on concomitant $C$ trachomatis infection in patients with genital warts. ${ }^{35}{ }^{20}$ Possible associations between HPV lesions and chlamydial cervicitis have been reported. ${ }^{38}$ The report published here shows the concomitant occurrence of $\boldsymbol{C}$ trachomatis cervicitis in women with cervical HPV infections who had been prospectively followed up to assess their natural history.

\section{Patients and methods}

We studied 418 consecutive women who had been included in a prospective follow up study of cervical HPV lesions since 1981. The women were asked to return whenever cytopathic changes induced by HPV were found in their routine cervical Pap smears, using the criteria outlined previously. ${ }^{23-26}$ All patients were studied at the outpatient department of gynecology and obstetrics, Kuopio University Central Hospital, Kuopio, Finland, as described previously. ${ }^{34}{ }^{35}$ The patients attended the clinic at six month intervals, and the length of follow up for each individual woman was planned to be at least five years. ${ }^{34}{ }^{35}$ At each attendance, a thorough gynecological examination including colposcopy, either with or without directed punch biopsy depending on whether or not the patient presented with concomitant CIN (HPV-CIN) or HPV but not CIN (HPV-NCIN), was undertaken.

Table I shows the age distribution of the study group. The age peak was 20 to 24 years, and $62 \cdot 2 \%$ of the women were aged under 30 years. Table II shows that the mean (SD) duration of follow up to the time of writing was $20 \cdot 1(15 \cdot 5)$ months.

TABLE I Ages of 418 women

\begin{tabular}{lc}
\hline Age (years) & No (\%) in age group \\
\hline $15-19$ & $65(15 \cdot 6)$ \\
$20-24$ & $125(29 \cdot 9)$ \\
$25-29$ & $70(16 \cdot 8)$ \\
$30-34$ & $60(14 \cdot 4)$ \\
$35-39$ & $40(9 \cdot 6)$ \\
$40-44$ & $21(5 \cdot 0)$ \\
$45-49$ & $16(3 \cdot 8)$ \\
Over 50 & $21(5 \cdot 0)$
\end{tabular}

Mean $(\mathrm{SEM})$ age $=28 \cdot 6(10 \cdot 2)$ years.

TABLE II Duration of follow up of 418 women

\begin{tabular}{lc}
\hline Follow up (months) & No (\%) attending \\
\hline Up to 4 & $105(25 \cdot 1)$ \\
$5-8$ & $47(11 \cdot 2)$ \\
$9-12$ & $20(4 \cdot 8)$ \\
$13-16$ & $40(9 \cdot 6)$ \\
$17-20$ & $25(6 \cdot 0)$ \\
$21-24$ & $50(12 \cdot 0)$ \\
$25-28$ & $30(7 \cdot 2)$ \\
$29-32$ & $28(6 \cdot 7)$ \\
$33-36$ & $34(8 \cdot 1)$ \\
$37-40$ & $25(6 \cdot 0)$ \\
After 40 & $14(3 \cdot 3)$ \\
\hline
\end{tabular}

Mean (SEM) duration of follow up $=20 \cdot 1(15 \cdot 5)$ months.

Whenever a punch biopsy was undertaken, three samples of cervical tissue were taken: one was processed for routine light microscopy, one for electron microscopy, and one was frozen immediately for immunohistochemical analyses and for DNA hybridisation. ${ }^{34}{ }^{35}$ In sections stained with haematoxylin and eosin, the morphology of the HPV lesions was analysed using the criteria outlined previously, ${ }^{23-26}$ and each lesion was classified into one of three categories of condyloma: flat, inverted, or papillary. The grade of CIN was assessed using the commonly accepted criteria for CIN I, II, and III. In each lesion, the intensity of the local immunocompetent cell infiltrate was graded into one of three categories: scanty, moderate, or dense, according to the overall density of the subepithelial infiltrate. The clinical course of the HPV lesions was classified as having either regressed, persisted, or progressed, based on the findings specific to HPV on colposcopy and Pap smear and in the punch 
biopsy specimen, as detailed previously. ${ }^{34}{ }^{35}$ The fresh tissue samples were frozen immediately in isopenthane cooled with liquid nitrogen, and stored at $-70^{\circ} \mathrm{C}$ until further processed. Cryostat sections were cut at $6 \mu \mathrm{m}$ thickness, and stained for immunocompetent cells using the ANAE (acid alpha-naphthyl acetate esterase) technique as described previously..$^{38}$ In sections stained with ANAE, T lymphocytes (ANAE $\mathrm{T}^{+}$cells) were recognised by their brown cytoplasmic spot like reactions, whereas mononuclear phagocytes (ANAE $\mathrm{M}^{+}$cells) showed diffuse brown cytoplasmic staining. Most cells that did not stain (ANAE-) were B lymphocytes ${ }^{38}$ In each biopsy specimen a total of 200 cells in randomly selected fields of the local infiltrate were counted, using a $63 \mathrm{x}$ objective equipped with an ocular grid, and the percentage of ANAE $\mathrm{T}^{+}$, ANAE $\mathrm{M}^{+}$, and ANAE ${ }^{-}$cells were established.

The $6 \mu \mathrm{m}$ cryostat sections were also stained for B lymphocytes and $T$ lymphocyte subsets using monoclonal antibodies and the avidin-biotin peroxidase complex $(\mathrm{ABC})$ technique, as detailed previously..$^{39}$ The following monoclonal antibodies were used: Leu-10 (Becton Dickinson, Sunnyvale, California, United States of America), which defines B lymphocytes; OKT-3 (Ortho Immunobiology Ltd, Raritan, New Jersey, USA), which reacts with all peripheral T lymphocytes; OKT-4 (Ortho) for T inducer or helper cells; OKT-6 (Ortho) for Langerhans cells; OKT-8 for T suppressor or cytotoxic cells; and HNK-1 (Becton Dickinson) to define NK (natural killer) and K (killer) cells. ${ }^{39}{ }^{40}$ Positive reactivity to each monoclonal antibody was manifested as a membrane or granular staining of lymphocytes in the subepithelial immunocompetent cell infiltrates and in the squamous epithelium. The percentages of cells reacting to the monoclonal antibodies (Leu-10 $0^{+}$, OKT $-3^{+}$, OKT $-4^{+}$, OKT $-6^{+}$, OKT $-8^{+}$and HNK $-1^{+}$) in the lesions were established as described above. The ratio of $T$ helper to $T$ suppressor cells was calculated in each specimen. All the cell counting procedures were completed in a blind manner, the examiner being unable to identify the specimens at this stage of the study.

At each visit (at six month intervals) to the clinic, cervical material was taken for culture of $C$ trachomatis using conventional methods as described previously. ${ }^{41}$. McCoy cells were grown in modified Eagle's medium (MEM) (Gibco Laboratories, Grand Island, New York, USA), containing $7.5 \%$ newborn calf serum, $0.03 \% \mathrm{w} / \mathrm{v}$ glutamine (Merck, Darmstadt, BRG), and $10 \mu \mathrm{g} / \mathrm{ml}$ gentamicin (Neofarma, Seinäjoki, Finland: licenced by the Schering Corporation). Clinical specimens in transport medium were diluted 1 in 4 in MEM modified for chlamydiae, containing $5 \%$ newborn calf serum, glutamine, gentamicin, $0.7 \% \mathrm{w} / \mathrm{v}$ glucose, and $25 \mathrm{U} / \mathrm{ml}$ mycostatin (Squibb \& Sons, Twickenham,
Middlesex, England). Overnight cultures of McCoy cells on $13 \mathrm{~mm}$ cover slips were inoculated with diluted specimens by centrifugation at $3000 \mathrm{x}$ g for 60 minutes. After incubation for four hours at $37^{\circ} \mathrm{C}$, the medium was replaced by fresh chlamydial medium containing fetal bovine serum instead of newborn calf serum and $1 \mu \mathrm{g} / \mathrm{ml}$ cycloheximide (Koch-Light Laboratories, Colnbrook, Buckinghamshire, England). The cultures were incubated at $37^{\circ} \mathrm{C}$ for three days. The cells were stained with iodine and examined for the typical inclusion bodies.

Where statistical calculations are shown, Student's $t$ test was used.

\section{Results}

Table III shows the detection rate of chlamydiae in urethral and cervical swabs in patients whose cervical Pap smears showed different degrees of atypia. Chlamydiae were isolated from $1.3 \%$ to $4.7 \%$ of patients. No direct relations seemed to exist between the findings in Pap smears and the detection of chlamydial cervicitis (or urethritis) in these patients. The lowest detection rates $(1.3 \%)$ in patients with class III smears and their total absence in those presenting with class IV Pap smears are noteworthy.

TABLE III Chlamydial isolation related to findings in cervical Papanicoloau (Pap) smears

\begin{tabular}{llrr}
\hline \multirow{2}{*}{$\begin{array}{llr}\text { Class of } \\
\text { Pap smear }\end{array}$} & $\begin{array}{l}\text { No of } \\
\text { smears }\end{array}$ & \multicolumn{2}{c}{ Uo (\%) with chlamydiae from: } \\
\cline { 3 - 4 } & 340 & $8(2 \cdot 4)$ & \multicolumn{1}{c}{ Cervix } \\
\hline Class I & $342(3 \cdot 5)$ \\
Class II & 362 & $17(4 \cdot 7)$ & $17(4 \cdot 7)$ \\
Class III & 149 & $2(1 \cdot 3)$ & $2(1 \cdot 3)$ \\
Class IV & 2 & $0(0 \cdot 0)$ & $0(0 \cdot 0)$ \\
Total & 853 & $27(3 \cdot 2)$ & $31(3 \cdot 6)$ \\
\hline
\end{tabular}

TABLE IV Chlamydial isolation related to degree of cervical intraepithelial neoplasia (CIN) associated with human papillomavirus (HPV)

\begin{tabular}{lccc}
\hline $\begin{array}{l}\text { Degree of } \\
H P V-C I N\end{array}$ & $\begin{array}{l}\text { No of } \\
\text { lesions }\end{array}$ & \multicolumn{2}{c}{ No (\%) with chlamydiae from: } \\
\cline { 4 - 4 } & 311 & $13(4 \cdot 2)$ & $15(4 \cdot 8)$ \\
HPV-NCIN & 87 & $3(3 \cdot 4)$ & $2(2 \cdot 3)$ \\
HPV-CIN I & 81 & $0(0 \cdot 0)$ & $1(3 \cdot 2)$ \\
HPV-CIN II & 31 & $0(0 \cdot 0)$ & $0(0 \cdot 0)$ \\
HPV-CIN III & 20 & $16(3 \cdot 6)$ & $18(4 \cdot 0)$ \\
Total & 449 & &
\end{tabular}

Table IV summarises the isolation of chlamydiae in relation to the severity of HPV associated CIN lesions in the punch biopsy. The presence of chlamydiae was not particularly associated with more severe degrees of 
HPV-CIN, the isolation rates from the cervix and the urethra being practically identical in HPV-NCIN, HPV-CIN I, and HPV-CIN II lesions. Noteworthy again was the total absence of chlamydial cervicitis in the 20 women with most severe (HPV-CIN III) cervical lesions.

Table V shows the correlation between the density of the local immunocompetent cell infiltrate in cervical HPV lesions and positive culture of chlamydiae in cervical and urethral swabs. Chlamydial infections seemed to be associated with dense inflammatory cell infiltrates more often $(6.9 \%)$ than with scanty $(4 \%)$ or moderate $(2.3 \%)$ infiltrates in both the cervix and the urethra, though the differences were not significant.

Table VI shows the distribution of the immunocompetent cells defined by the ANAE technique in the biopsy specimens derived from cervical lesions positive or negative for chlamydiae. The percentages of ANAE, ANAE $\mathrm{T}^{+}$, and ANAE $\mathrm{M}^{+}$cells were identical in both groups.

Table VII shows the percentages of the immunocompetent cell subpopulations phenotypically identified by monoclonal antibodies in cervical lesions positive or negative for chlamydiae. No major differences existed between these two groups with regard to the relative proportions of $B$ and $T$ lymphocytes and $T$ helper, $T$ suppressor, Langerhans, and NK or K cells, or the ratio of T helper to $T$ suppressor cells, which remained close to 1 in both groups.

Table VIII summarises chlamydial isolation from
TABLE V Intensity of local immunocompetent cells (ICC) infiltrate related to chlamydial isolation from cervix or urethra or both

\begin{tabular}{lllll}
\hline & & \multicolumn{3}{c}{ No (\%) with chlamydiae from: } \\
\cline { 3 - 5 } $\begin{array}{l}\text { Intensity } \\
\text { of ICC } \\
\text { infiltrate }\end{array}$ & $\begin{array}{l}\text { No of } \\
\text { patients }\end{array}$ & Urethra & Cervix & Both \\
\hline Scanty & 175 & $4(2 \cdot 3)$ & $7(4 \cdot 0)$ & $2(1 \cdot 1)$ \\
Moderate & 133 & $5(3 \cdot 8)$ & $3(2 \cdot 3)$ & $1(0 \cdot 8)$ \\
Dense & 104 & $6(5 \cdot 8)$ & $7(6 \cdot 7)$ & $4(3 \cdot 9)$ \\
Total & 412 & $15(3 \cdot 6)$ & $17(4 \cdot 1)$ & $7(1 \cdot 7)$ \\
\hline
\end{tabular}

TABLE VI ANAE definable immunocompetent cells related to chlaymdial isolation in 511 cervical swabs

\begin{tabular}{|c|c|c|c|c|}
\hline \multirow[b]{2}{*}{$\begin{array}{l}\text { Chlamydial } \\
\text { isolation }\end{array}$} & \multirow[b]{2}{*}{$\begin{array}{l}\text { No of } \\
\text { swabs }\end{array}$} & \multicolumn{3}{|c|}{ Mean (SEM) immunocompetent cells } \\
\hline & & $A N A E^{-}$ & $A N A E T^{+}$ & $A N A E M^{+}$ \\
\hline $\begin{array}{l}\text { Positive } \\
\text { Negative }\end{array}$ & $\begin{array}{r}43 \\
468\end{array}$ & $\begin{array}{l}90.3(0.98) \\
89.6(0.34)\end{array}$ & $\begin{array}{l}5.3(0.58) \\
5.7(0.19)\end{array}$ & $\begin{array}{l}4.4(0.48) \\
4.7(0.17)\end{array}$ \\
\hline
\end{tabular}

ANAE $^{-}$cells $=$B lymphocytes .

ANAE $\mathrm{T}^{+}$cells $=\mathrm{T}$ lymphocytes.

ANAE $\mathrm{M}^{+}$cells $=$mononuclear phagocytes.

cervical compared with urethral swabs of patients whose HPV lesions had taken different clinical courses. Isolation of chlamydiae in either of these

TABLE VII Phenotypes of local immunoreactive cells in cervical biopsy specimens related to chlamydial isolation in 476 cervical swabs

\begin{tabular}{|c|c|c|c|c|c|c|c|c|}
\hline \multirow[b]{2}{*}{$\begin{array}{l}\text { Chlamydial } \\
\text { isolation }\end{array}$} & \multirow[b]{2}{*}{$\begin{array}{l}\text { No of } \\
\text { swabs }\end{array}$} & \multicolumn{6}{|c|}{ Mean (SEM) immunocompetent cell phenotypes: } & \multirow{2}{*}{$\begin{array}{l}\text { Mean (SEM } \\
\text { ratio of } \\
\text { OKT4 } \\
\text { OKT }^{+}\end{array}$} \\
\hline & & $\mathrm{OKT3}^{+}$ & $O K T 4^{+}$ & $\mathrm{OKT6}^{+}$ & OKT8 ${ }^{+}$ & $\mathrm{LEU} 10^{+}$ & $\mathrm{HNK} 1^{+}$ & \\
\hline $\begin{array}{l}\text { Positive } \\
\text { Negative }\end{array}$ & $\begin{array}{r}42 \\
434\end{array}$ & $\begin{array}{l}18.1(1.5) \\
18.3(0.4)\end{array}$ & $\begin{array}{r}10.1(1 \cdot 1) \\
9.7(0.3)\end{array}$ & $\begin{array}{l}2 \cdot 1(0 \cdot 3) \\
1.9(0 \cdot 1)\end{array}$ & $\begin{array}{l}13 \cdot 1(1 \cdot 0) \\
12 \cdot 1(0 \cdot 4)\end{array}$ & $\begin{array}{l}49 \cdot 7(2 \cdot 1) \\
47 \cdot 7(0 \cdot 7)\end{array}$ & $\begin{array}{l}1.6(0.2) \\
1.7(0.1)\end{array}$ & $\begin{array}{l}0.83(0.07) \\
0.92(0.08)\end{array}$ \\
\hline
\end{tabular}

TABLE VIII Chlamydial isolation from urethra or cervix in relation to clinical course of human papillomavirus (HPV) lesions

\begin{tabular}{lrrrr}
\hline \multirow{2}{*}{$\begin{array}{l}\text { Chlmaydial } \\
\text { isolation }\end{array}$} & $\begin{array}{l}\text { No of } \\
\text { swabs }\end{array}$ & Regressed & Persisted & Progressed \\
\cline { 5 - 6 } & 1187 & $363(30 \cdot 6)$ & $616(51 \cdot 9)$ & $208(17 \cdot 5)^{*}$ \\
Negative & 29 & $7(24 \cdot 1)$ & $20(69 \cdot 0)$ & $2(6 \cdot 9)$ \\
Positive from urethra or cervix & 9 & $1(11 \cdot 1)$ & $8(88 \cdot 9)$ & $0(0 \cdot 0)$ \\
Positive from urethra and cervix & 1225 & $371(30 \cdot 3)$ & $644(52 \cdot 6)$ & $210(17 \cdot 1)$ \\
Total & & &
\end{tabular}

\footnotetext{
* Includes $86(7 \cdot 2 \%)$ lesions that coned due to progression to carcinoma in situ.
} 
specimens separately or together was not specifically associated with clinical progression of the HPV lesions.

\section{Discussion}

Several epidemiological surveys have suggested that $C$ trachomatis might have a relation to CIN. ${ }^{6} 7127-19$ These data are based on the finding of serum antibodies to chlamydiae in a higher proportion of women with $\mathrm{CIN}$ than in controls. In one study Pap smears showed class II or III cells in 11 of 15 women with serum chlamydial antibodies in contrast to only three of 18 of patients without chlamydial antibodies. ${ }^{13}$ In another study, $C$ trachomatis was isolated from $16 \%$ of 177 gynecological outpatients with CIN. On the other hand, only $4 \cdot 1 \%$ of women in another study were infected. ${ }^{17}$ Another report showed that women with CIN had twice as great a risk of having serum antibodies to $C$ trachomatis than did matched controls, whereas no such risk was found in these women for antibodies to HSV. ${ }^{19}$ Despite the ubiquity of $C$ trachomatis, this agent has never been shown to possess oncogenic potential in vitro, and the above results should be interpreted cautiously. ${ }^{2} 919$

The possibility that $C$ trachomatis could act synergistically with some other infectious agents in inducing CIN cannot be ruled out, however, on the basis of the reports cited above. ${ }^{18}$ Indeed, an interesting hypothesis has been presented, which suggests that HSV could act synergistically with HPV in cervical carcinogenesis. ${ }^{36}$ This concept was based on experimental observations of HSV acting as an initiator in oncogenesis, in contrast to HPV, which seems to act as a promotor. ${ }^{22}{ }^{36}$ This hypothesis is supported by the fact that most HPV lesions seem to require a cocarcinogen (physical or chemical agent) to undergo malignant transformation. ${ }^{21} 22{ }^{36} \mathrm{~A}$ recent report established that $10 \%$ of the prospectively followed up women with cervical HPV infection might have coexistent chlamydial cervicitis, ${ }^{41}$ but the data were not correlated with the clinical behaviour of the cervical HPV lesions. Such data would, however, be essential to establish the concept of chlamydiae being implicated in the development of CIN lesions and eventually cervical carcinoma. ${ }^{6} 712$ 17-19

The experimental design of this study permitted access to the prospective follow up data on cervical HPV infections for the first time and made possible the assessment of the factors influencing the clinical behaviour of HPV infections, including the synergism hypothesis. ${ }^{34}{ }^{35}$ Chlamydial infection is seated more deeply in the endocervix than is that of HPV, which affects the transformation zone and mature squamous epithelium. ${ }^{32}$ Consistent with this, detection of cells infected with chlamydiae in Pap smears seems to be unpredictable, and the specificity of cytological changes in Pap smears induced by chlamydiae is a controversial issue. ${ }^{6}{ }^{712-15}$ The present results show that chlamydial cervicitis does not bear any relation to the degree of cellular atypia in Pap smears of patients infected with HPV (table III). Indeed, chlamydial infection was least common in patients with class III cells and never occurred with class IV cells. This contradicts previous observations that suggested a close association of chlamydiae with class II and III cells. ${ }^{13}$ We emphasise that no attempt was made in the present study to identify chlamydiae in Pap smears. ${ }^{12-15}$

The prevalence of chlamydial cervicitis has been shown to range from $19 \%$ to $33 \%$ in women attending STD clinics.9 ${ }^{9}$ These data were collected from 10 different clinics in Europe and the United States of America, and were based on analyses of more than 4000 women.' Figures from gynecological outpatient clinics were somewhat lower (8-9\%). ${ }^{517}$ These figures were recently shown to agree with those for our patients, $10.4 \%$ of whom showed positive cultures for chlamydiae. ${ }^{41}$ In previous studies, the prevalence of $C$ trachomatis infection in patients with condyloma varied from $0 \%(0 / 8 \text { patients })^{5}$ to $15 \cdot 4 \%(2 / 23$ patients). ${ }^{3}$ These figures of course are skewed by the small number of patients. In a recent series of $69 \mathrm{CIS}$ and invasive cerivcal carcinomas, $19(27.5 \%)$ showed HPV and $17(24.6 \%) C$ trachomatis infection. ${ }^{20}$ In the present series, chlamydiae were cultured from $4.1 \%$ of the cervical swabs and $3.6 \%$ of the urethral samples (table II). No direct correlation between chlamydial cervicitis and the grade of HPV-CIN could be established. The present rates agree with those $(4 \cdot 1 \%)$ reported before in a series of CIN patients, ${ }^{17}$ but are considerably lower than those reported by other workers. ${ }^{6}$ Our findings do not support the view that chlamydiae have any major relation to CIN. ${ }^{6} 712$ 17-19

In biopsy specimens, most cervices infected with chlamydiae show non-specific inflammatory changes only, ${ }^{7}$ though more specific follicular cervicits ${ }^{10}$ and intraepithelial vesicles containing the different developmental stages of chlamydiae have also been described. ${ }^{1}$ So far, the inflammatory reactions associated with chlamydial cervicitis are almost unknown. The same is true of the analysis of the local immunocompetent cell infiltrates in cervical HPV lesions. ${ }^{38} 3940$ In the present study, such infiltrates were analysed using the ANAE technique and monoclonal antibodies to define the subsets of the immunocompetent cells. Chlamydial isolation was associated with dense inflammatory infiltrate more often than with scanty or moderate reactions (table V). This agrees with the current views on the life cycle of chlamydiae in genital tract infections. ${ }^{1} 710$ ANAE cells (B lymphocytes) mediating humoral immune reactivity predominated in the local infiltrates (table VI). This has also been shown in cervical HPV lesions, 
where no major differences existed in ANAE definable cells between the different types of lesions or degree of HPV-CIN ${ }^{38}$ This is also evident at the level of immunocompetent cell subpopulations, including the ratio of $T$ helper to $T$ suppressor cells (reflecting the immunoregulatory balance) (table VII). The number of HNK-1 ${ }^{+}$NK cells were also identical in lesions positive and negative for chlamydia, which agreed with observations on NK cells in the peripheral blood of such patients. ${ }^{43}$ Thus, chlamydiae cervicitis coexistent with an HPV infection does not seem to modify to any appreciable extent the local immune reaction pattern against HPV infection.

The results published here also clearly indicate that coexistent chlamydial cervicitis does not modify the clinical course of cervical HPV infections (table VIII). The natural history of the cervical HPV infections are discussed in detail in a separate report. ${ }^{34}$ Thus the present results do not provide evidence substantiating the hypothesis that chlamydiae and HPV act synergistically in cervical carcinogenesis. In such a case one would expect more aggressive behaviour of HPV lesions, identifiable by the prospective follow up. ${ }^{34}$ In conclusion, the present results do not substantiate the view that $\boldsymbol{C}$ trachomatis is a major aetiological agent of CIN lesions. Chlamydiae and HPV are covariables of sexual behaviour, ${ }^{25-9} 20$ and their concomitant appearance in sexually promiscuous women ${ }^{25}$ is best explained by this fact. In large scale epidemiological studies, these same factors (early onset of sexual activity, multiple partnerships, poor hygiene) also predispose to cervical cancer. ${ }^{25}$ Thus the increased prevalence of chlamydiae reported in patients with $\mathrm{CIN}^{6}{ }^{713}{ }^{17-19}$ does not prove a causal relation. ${ }^{2}{ }^{9}$ Until we have more direct evidence for the oncogenic potential of $C$ trachomatis (as we have of HPV), it seems reasonable not to consider this agent as a major cause of CIN, but rather a sexually transmitted agent commonly found in these women with CIN because of their promiscuous sexual behaviour.

This work was supported in part by a research grant (number 07/014) from the Medical Research Council of the Academy of Finland, and in part by a research grant from the Finnish Cancer Society. We thank Mrs Heli Eskelinen, Miss Helena Kemiläinen, Mrs Maritta Lipponen, and Miss Ritva Savolainen for their skilful technical help.

\section{References}

1. Swanson J, Eschenbach DA, Alexander ER, Holmes KK. Light and electron microscopic study of Chlamydia trachomatis infection of the uterine cervix. J Infect Dis 1975;131:678-87.

2. Briggs RM, Paavonen J. Cervical intraepithelial dysplasia. In: Holmes KK, Mårdh P-A, Sparling PF, Weisner PJ, eds. Sexually transmitted diseases. New York: McGraw-Hill. 1984: 589-615.
3. Oriel JD, Powis PA, Reeve P, Miller A, Nicol CS. Chlamydial infections of the cervix. British Journal of Venereal Diseases 1974;50:11-6.

4. Oriel JD, Johnson AL, Barlow D, Thomas BJ, Nayyar K, Reeve P. Infections of the uterine cervix with Chlamydia trachomatis. J. Infect Dis 1978;137:443-51.

5. Paavonen J, Saikku P, Vesterinen E, Meyer B, Vartiainen E, Saksela $E$. Genital chlamydial infections in patients attending a gynaecological outpatient clinic. British Journal of Venereal Diseases 1978;54:257-61.

6. Paavonen J, Vesterinen E, Meyer B, Saikku P, Suni J, Purola E, Saksela E. Genital Chlamydia trachomatis infections in patients with cervical atypia. Obstet Gynecol 1979;54:28991.

7. Paavonen J. Chlamydia trachomatis infections in the female genital tract. Helsinki: University of Helsinki, 1979. MD Thesis. 1-85.

8. Taylor-Robinson D, Thomas BJ. The role of Chlamydia trachomatis in genital-tract and associated diseases. $J$ Clin Pathol 1980;33:205-33.

9. Thompson SE, Washington AE, Epidemiology of sexually transmitted Chlamydia trachomatis infections. Epidemiol Rev 1983;5:96-123.

10. Hare MJ, Toone E, Taylor-Robinson D, et al. Follicular cervicitis - colposcopic appearances and association with Chlamydia trachomatis. Br J Obstet Gynaecol 1981;88:174 80.

11. Hilton AL, Richmond SJ, Milne JD, Hindley F, Clarke SKR. Chlamydiae A in the female genital tract. British Journal of Venereal Diseaes 1974;50:1-10.

12. Carr MC, Hanna L, Jawetz E. Chlamydiae, cervicitis, and abnormal Papanicolaou smears. Obstet Gynecol 1979;53:27-30.

13. de Borges RJ, Carmona O, Machado H, Esparza J. Chlamydial infection in Papanicolaou-stained cervical smears. Acta Cytol (Baltimore) 1984;28:471-6.

14. Medley G. Cytological diagnosis of chlamydial infections of female genital tract. Lancet 1983;i:1449.

15. Gupta PK, Lee EF, Erozan YS, Frost JK, Geddes ST, Donovan PA. Cytologic investigation in chlamydia infection. Acta Cytol 1979;23:315-20.

16. Oriel JD. Chlamydiae and viruses causing human sexually transmitted diseases-analogies with infections in animals: a review. J Roy Soc Med 1983;76:602-8.

17. Schachter J, Hill EC, King EB, Coleman VR, Jones P, Meyer $\mathrm{KF}$. Chlamydial infection in women with cervical dysplasia. Am J Obstet Gynecol 1975;123:753-7.

18. Schachter J. Sexually transmitted infections and cervical atypia. Sex Transm Dis 1981;8:353-6.

19. Schachter J, Hill EC, King EB, et al. Chlamydia trachomatis and cervical neoplasia. JAMA 1982;248:2134-8.

20. Allerding TJ, Jordan S. Association of human papillomavirus and chlamydia infections with incidence of cervical neoplasia. Acta Cytol 1983;27:553.

21. zur Hausen $\mathbf{H}$. Human papillomaviruses and their possible role in squamous cell carcinomas. Curr Top Microbiol Immunol 1977;78:1-30.

22. zur Hausen H, Gissmann L, Schlehofer JR. Virusus in the etiology of human genital cancer. Prog Med Virol 1984;30:170 86.

23. Syrjänen $\mathrm{KJ}$. Current views on the condylomatous lesions in uterine cervix and their possible relationship to cervical squamous cell carcinoma. Obstet Gynecol Surv 1980;35:68594.

24. Syrjänen KJ. Human papillomavirus (HPV) lessions in association with cervical dysplasias and neoplasias. Obstet Gynecol 1983;62:617-24.

25. Syrjänen $\mathrm{K}$, Väyrynen $\mathrm{M}$, Castrén $\mathrm{O}$, et al. Sexual behaviour of women with human papillomavirus (HPV) lesions of the uterine cervix. British Journal of Venereal Diseases 1984;60:243-8

26. Syrjänen $\mathrm{KJ}$. Current concepts on human papillomavirus 
(HPV) infections in the genital tract and their relationship to intraepithelial neoplasia and squamous cell carcinoma. Obstet Gynecol Surv 1984;39:252-65.

27. de Brux J, Orth G, Croissant O, Cochard B, Ionesco M. Lesions condylomateuses du col uterin: evolution chez 2466 patientes. Bull Cancer (Paris) 1983;70:410-22.

28. Fu YS, Reagan JW, Richart RM. Precursors of cervical cancer. Cancer Surveys 1983;2:359-82.

29. Dürst M, Gissmann L. Ikenberg H, zur Hausen H. A papillomavirus DNA from a cervical carcinoma and its prevalence in cancer biopsy samples from different geographic regions. Proc Natl Acad Sci USA 1983;80:3812-4.

30. Bochart M, Gissmann L, Ikenberg H, Kleinheinz A, Scheurlen W, zur Hausen $H$. A new type of papillomavirus DNA, its presence in genital cancer biopsies and in cell lines derived from cervical cancer. European Molecular Biology Organisation Journal 1984;3:1151-7.

31. Gissmann L, Boshart M, Dürst M, Ikenberg H, Wagner D, zur Hausen $H$. Presence of human papillomavirus in genital tumors. J Invest Dermatol 1984;83:26-8.

32. Gissmann L. Papillomaviruses and their association with cancer in animals and in man. Cancer Surveys 1984;3:161-81.

33. Pfister H. Biology and biochemistry of papillomaviruses. Rev Physiol Biochem Pharmacol 1984;99:112-81.

34. Syrjänen K, Väyrynen M, Saarikoski S, et al. Natural history of cervical human papillomavirus (HPV) infections based on prospective follow-up. Br J Obstet Gynaecol (in press).

35. Syrjänen K, de Villiers E-M, Saarikoski S, et al. Cervical papillomavirus infection progressing to invasive cancer in less than three years. Lancet 1985; i:510-1.
36. zur Hausen $\mathbf{H}$. Human genital cancer: synergism between two virus infections or synergism between a virus infection and initiating events? Lancet 1982;ii:1370-2.

37. Syrjänen $\mathrm{K}, \mathbf{M a ̈ n t y j a ̈ r v i ~} \mathrm{R}$, Väyrynen $\mathbf{M}$, et al. Herpes simplex virus infection of females with human papillomavirus (HPV) lesions in the uterine cervix. Cervix 1984;2:25-32.

38. Syrjänen $\mathrm{KJ}$. Immunocompetent cells in uterine cervical lesions of human papillomavirus (HPV) origin. Gynecol Obstet Invest 1984;16:327-40.

39. Syrjänen K, Väyrynen M, Mäntyjärvi R, Castrén O, Saarikoski S.Natural killer (NK) cells with HNK-1 phenotype in the cervical biopsies of women followed up for human papillomavirus (HPV) lesions. Acta Obstet Gynecol Scand (in press).

40. Väyrynen M, Syrjänen K, Mäntyjärvi R, Castrén O, Saarikoski S. Immunophenotypes of lymphocytes in prospectively followed up human papillomavirus lesions of the cervix. Genitourin Med 1985;61:190-6.

41. Syrjänen $K$, Mäntyjärvi, R. Väyrynen M, Castrén O, Yliskoski M, Saarikoski S. Chlamydial cervicitis in women followed up for human papillomavirus (HPV) lesions of the uterine cervix. Acta Obstet Gynecol Scand 1985;64:467-71.

42. Adam E, Kaufman RH, Adler-Storthz K, Melnick JL, Dreesman GR. A prospective study of association of herpes simplex virus and human papillomavirus infection with cervical neoplasia in women exposed to diethylstilbestrol in utero. Int J Cancer 1985;35:19-26.

43. Onsrud M, Qvigstad E. Natural killer cell activity after gynecologic infections with chlamydia. Acta Obstet Gynecol Scand 1984;63:613-5. 